\title{
Ultra-high resolution mapping of protein-genome interactions using ChIP-exo
}

\author{
B Franklin Pugh \\ From Beyond the Genome 2012 \\ Boston, MA, USA. 27-29 September 2012
}

\begin{abstract}
With the advent of high-throughput and high resolution genome-wide protein-DNA detection assays, the interrelationships between chromatin and the transcription machinery are now becoming clearer. Here I will discuss our recent findings using MNase ChIP-seq to map nucleosome positions, and a novel ultra-high resolution mapping technique called ChIP-exo that we recently developed [1]. What is apparent from these studies is the following: firstly, transcription factors bind to many more locations in the genome than previously appreciated. Secondly, PICs form at the interface between nucleosomes and nucleosome-free promoter regions. Finally, Chromatin remodeling complexes target specific nucleosome positions, working in concert to organize nucleosomes at the beginning and end of genes. Many remodeler subunits interact asymmetrically with the nucleosome core across the genome, which may be important for the directional passage of RNA polymerase II.
\end{abstract}

Published: 1 October 2012

\section{Reference}

1. Rhee HS, Pugh BF: Comprehensive genome-wide protein-DNA

interactions detected at single-nucleotide resolution. Cell 2011, 14:1408.

Submit your next manuscript to BioMed Central and take full advantage of:

- Convenient online submission

- Thorough peer review

- No space constraints or color figure charges

- Immediate publication on acceptance

- Inclusion in PubMed, CAS, Scopus and Google Scholar

- Research which is freely available for redistribution

\section{Biomed Central}

